urn:lsid:zoobank.org:pub:BC058290-4F17-4010-8A63-0B96FB2A302F

\title{
Two new genera of Pteronemobiini crickets from the Brazilian Atlantic forest (Orthoptera, Grylloidea, Trigonidiidae, Nemobiinae)
}

\author{
MARCIO P. BOLFARINI ${ }^{1}$, RENATO S. CAPELLARI ${ }^{2} \&$ FRANCISCO DE A. G. DE MELLO $^{1,3}$ \\ ${ }^{1}$ Universidade Estadual Paulista "Júlio de Mesquita Filho", Instituto de Biociências, Departamento de Zoologia. Distrito de Rubião \\ Júnior, s/n, 18618-000 Botucatu, São Paulo, Brazil \\ ${ }^{2}$ Universidade de São Paulo, Faculdade de Filosofia, Ciências e Letras de Ribeirão Preto, Departamento de Biologia, Avenida Ban- \\ deirantes, 3900, 14040-901, Ribeirão Preto, SP, Brazil \\ ${ }^{3}$ Corresponding author.E-mail: framello@ibb.unesp.br
}

\begin{abstract}
Two new genera and species of Pteronemobiini crickets (Grylloidea: Trigonidiidae: Nemobiinae) are described from southern Brazilian Atlantic Forest: Kevanemobius paulistorum gen. n. et sp. n., and Pepoyara jagoi gen. n. et sp. n. The position of these genera among other Pteronemobiini is briefly discussed.
\end{abstract}

Key words: Orthoptera, Grylloidea, Nemobiinae, Pteronemobiini, New Taxa, Atlantic Forest, South America

\section{Resumo}

Dois novos gêneros e espécies de grilos Pteronemobiini (Grylloidea: Trigonidiidae: Nemobiinae) são descritos do sul da Mata Atlântica Brasileira: Kevanemobius paulistorum gen. n. et sp. n., e Pepoyara jagoi gen. n. et sp. n. A posição desses gêneros, entre outras de Pteronemobiini, é brevemente discutida.

Palavras-chave: Orthoptera, Grylloidea, Nemobiinae, Pteronemobiini, Novos Táxons, Mata Atlântica, Novos Táxons, América do Sul

\section{Introduction}

Currently, the subfamily Nemobiinae bears six tribes, being Marinemobiini and Grylliscini distributed in Eastern Europe, Theteliini in the Australian continent and Japan, Hemigrillini in South America, Nemobiini in all continents except North America, and Pteronemobiini distributed across the globe with the exception of permanently ice-covered areas. Vickery (1970) has placed three genera of North American nemobiines, Allonemobius Hebard, Neonemobius Hebard, and Eunemobius Hebard, as well as many other genera from the Old World in the tribe Pteronemobiini, which is characterized by the glandular condition of the supero-internal dorsal spur on male hind tibiae. Other genera, in which that spur is not glandular, were included in the tribe Nemobiini. De Mello (1990) described the genus Zucchiella based on a single species, Z. atlantica, from the forests of eastern Brazil and, due to the absence of such glandular spur, placed it in the Nemobiini.

Desutter (1990), in her study on Neotropical crickets, recognized three groups of Nemobiinae: Group Pteronemobius, comprising species of genus Pteronemobius, including those from the neartic region, and Group Argizala, monotypic, strictly neotropical (both bearing a glandular supero-internal spur on male hind tibiae); and Group Hygronemobius, comprising two genera: Hygronemobius and Absonemobius, plus some undescribed species from the mountains of Colombia (in this group the supero-internal dorsal spur of hind tibiae is not glandular). The Nemobiinae has traditionally been placed in the family Gryllidae, but Gorochov (1986) and Desutter (1987, 1990) agree that it should be combined with the Trigonidiinae to form a single group (family Trigonidiidae). 